\title{
循環器疾患の予見, 予防へのアプローチ
}

\author{
日野原 茂 雄
}

\section{緒 言}

近年，わが国では脳血管疾患による死亡は著しい減少 傾向を示しているが，心缄病による死亡に減少傾向はな く，なかでも虚血性心疾患は増加の一途をたどってい る。一方，虚血性心疾患が世界一高頻度であった米国が 一次予防の全国民的実践により，心筇硬塞による死亡率 を1977年に至る 8 年間で実に $22.6 \%$ 低下させ得た事実 は Stamler ${ }^{1)}$ の報告に詳しいが，生活の欧米化著しいわ が国にとっては参考にすべき点が多い。生活習慣の改善 による成人病の予防は一次予防と呼ばれ, 二次予防に比 較して延命効果が大きいものであり，今回はこの一次予 防の観点より健診受診者の連続受診による効果を検討 し，さらに予見，予防へのアプローチを試みたので報告 したい。

\section{対象と方法}

対象は, 当センター発足当初より1978年 3 月迄の受診 者のらち，1983年 3 月末までに 5 回の連続健診をした 30 〜49歳までの男性365名，女性71名の合計436名である。 女性は対象者が少いため男性の所見を主に検討した。対 象を血清総コレステロール值のヒストグラムにより， A, B, C の 3 群に分け, 各群の占める人数がほぼ同数にな るように分類した。ヒストグラムより得られたコレステ ロール值はA群が $175 \mathrm{mg} / \mathrm{dl}$ 以下, B群は176〜200 mg $/ \mathrm{dl}$ 末満, C群は $200 \mathrm{mg} / \mathrm{dl}$ 以上となった。これら 3 群 各々の有する他の危険因子の所有状況と連続受診による 推移を平均值を基として検討した。

\section{I. 成 績}

1. 心電図異常所見所有率

これについては連続受診の第 5 回目だけの所有率を比 較したが，心電図異常所見所有率はA群で3.9\%, B群で は6.8\%, C群では $8.3 \%$ と、コレステロールが高めの C 群では, 低めのA群に比較して 2 倍以上の高頻度で心電 図異常がみられた。

\section{An approach to the primary prevention of coronary heart disease}

東海大学病院健診センター

\section{2. 肥満度および血圧}

肥満度はコレステロール值の高い群ほど大であり, 連 続受診によってC群にはやや改善傾向がみられたが，5 回受診とも A， B， Cの順位は不变であった。血圧は, 収縮期, 拡張期とも 3 群間に差はなかったが, 受診回数 の増すにつれ 3 群ともやや低下する傾向がみられた。

3. 血液生化学測定值

血清尿酸值は $\mathrm{A}$ 群が低く, B 群は C 群より僅かに低值 であった。各群とも受診回数の増すにつれ上昇し, 順位 は連続受診によっても不変であった。血清トリグリセラ イド值は A, B, C 群の順に高く, 連続受診による順位 は不変であり, 上昇傾向を認めた。血清総コレステロー ル值は血清トリグリセライド值と同様の傾向を示し, 連 続受診による低值化は認められなかった。

4. 生活一般事項

契煙, 飲酒習慣, 運動および車の運転 1 日 3 時間以上 （車の運転は坐位の作業と同一と考えた）の 4 項目につ いて検討したが，運動不足は 3 群共通して高率であり， いずれの項目の所有率にも連続受診による生活習慣の著 しい改善は認められなかった。

要するに危険因子所有状況は連続受診により，血圧以 外は改善傾向が全く認められていない。連続健診受診は 一次予防にあまり役立てられていないことが明らかとな った。

\section{II. 予見，予防へのアプローチ}

健診の連続利用が一次予防に役立てられるためには， 危険因子を主とする健診情報が受診者に把握され易い形 で提供され，その情報に基づいて指導されることが望ま しい。リスクファクターの把握は疾患に対する予知を可 能とするものであり，予知，予防へのアプローチは健診 情報の受診者への伝達法の明解化, 具体的啓蒙法にある ものと考兄られた。したがって，われわれは今回予見， 予防のためのアプローチとして図 1 の如き指導表の作成 を試みた。即ち円の上半分に主に問診情報，下半分に測 定值をプロットし，各得点を線で結んだパターンが円に 近似なほどリスクファクター所有率が低く，望ましいパ 
図 1-a 予知予防のための指導表モデルパターン

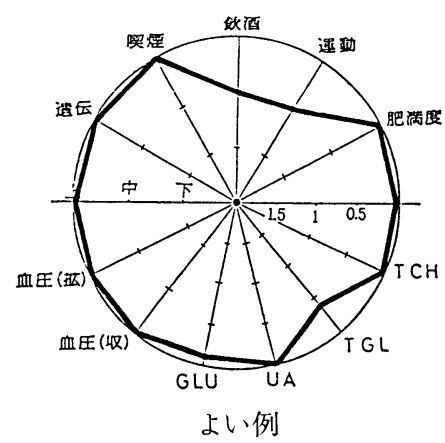

よい例

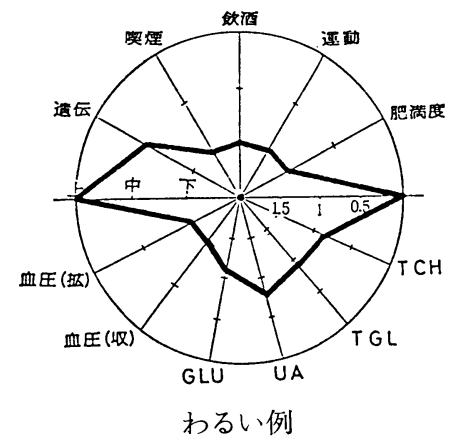

わるい例

図 1-b 3 群の予知・予防のための指導表

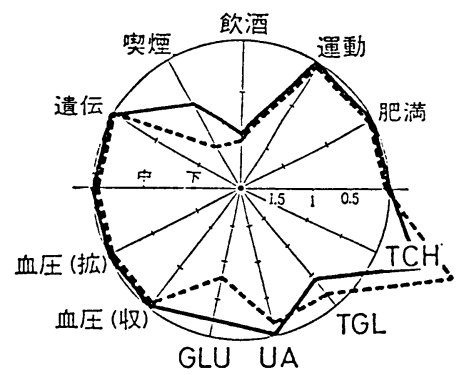

A 群

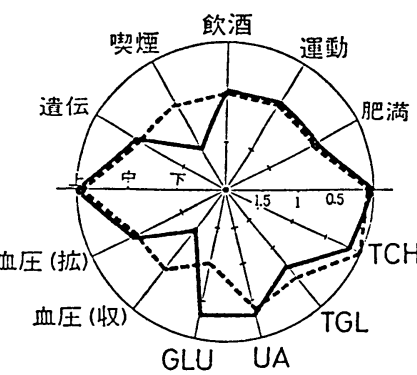

B 群

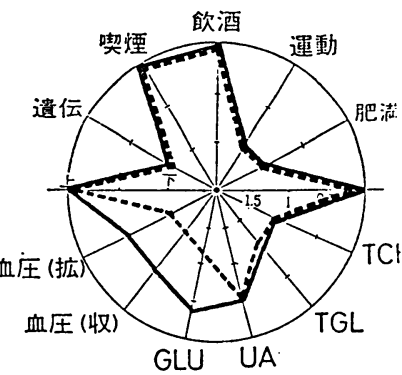

C群
ターンとした。図 $1 \mathrm{a}$ が良い例と悪い例のモデルであ り, bの直線で表わしたパターンは今回の検討対象群 A， B，Cの集団としてのパターンである。

点線で表わしたパターンはコントロール群であり，検 討群と同一年代の男性 1,794 名を最近, 即ち 1982 年度の 初回受診者中より遙び, 同様にコレステロール值レベル により $\mathrm{A} ， \mathbf{B} ， \mathrm{C} の 3$ 群に分けて表わしたものである。 興味あることに $\mathrm{A}, \mathrm{B}, \mathrm{C}$ 群のパターンは検討群とコン トロール群では極めて類似したものであった。ここでも 連続受診の効果が得られていないことが示された。また， コントロール群の「狭心症, 又は心筋硬塞の家族歴所有 率」をみたが，A群では $5.2 \% ， \mathrm{~B}$ 群 7\%，C群 9.4\%で あった。これは検討群の心電図異常所見所有率と同様の 傾向でもある。しかし，自動化総合健診にとってょり重 要なものは個人指導表パターンである。したがってつぎ に個人指導表作成の試みをおこなった。図 2 の 作成に使用した項目別の得点表である。図 2 の b は健診 受診以降に心筋硬塞を起こした 4 例の健診受診時データ によって作成した個人指導表パターンである。症例 1 は 67歳の男性で, 職業は医師。パターンは多くの項目に凹
があるが他症例のパターンに比較するとパターンは最大 である。この症例は健診の 4 年 4 力月後に心筋硬塞を発 症した。症例 2 は61歳の男性で管理職。症例 3 は47歳の 男性で管理職。症例 4 は55歳の男性で会社員。症例 1 か ら症例 4 の順にパターンは縮小しており, 健診から心筋 硬塞発症までの期間は症例 2 で 2 年 1 カ月。症例 3 で 8 カ月。症例 4 で 6 力月と, パターンが縮小するに従って 健診から硬塞発症までの期間は短くなった。これら症例 間のパターンの差は予見の可能性を示唆するものであ り, 縮小したパターン所有者には予防即ちパターンの拡 大への決意を促すものである。

\section{考 察}

1969年, WHO（世界保健機構）は次の如き勧告を発 表している2）。即ち，「虚血性心疾患は蔓延し，しかも若 い年代に払大しつつある。近い将来には人類最大の流行 病となりらる盧が大きい。したがって各国は予防に対す る研鑚に努力して欲しい。」といった内容のものである。 この勧告の出された 2 年後にあたる 1971 年に Stamler ${ }^{1}$ は Acute myocardial infarction-progress in primary prevention と題する総説を発表しているが，心筋硬塞の一 
図 2-b 健診者の心筋硬塞実際例

図 2-a 指導表の得点基準

\begin{tabular}{|c|c|c|c|c|}
\hline 不首会得点 & 1 & 2 & 3 & 4 \\
\hline 遗伝素因 & な し & $\begin{array}{l}\text { 想公母 } \\
\text { 小ずれか }\end{array}$ & \begin{tabular}{|l|} 
禹親 \\
いずれか
\end{tabular} & 両 方 \\
\hline 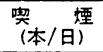 & な し & $\sim 20$ & -40 & $41 \sim$ \\
\hline 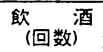 & な し & 週2 3回 & 週4－5回 & 日 \\
\hline 饮 $_{(\text {船) }}$ 酒 & な し & 少ない & ....... & 多 い \\
\hline 運動 & 毎 日 & 週4 6日位 & 週1－2日 & $\begin{array}{l}\text { ほとんと } \\
\text { しない }\end{array}$ \\
\hline
\end{tabular}

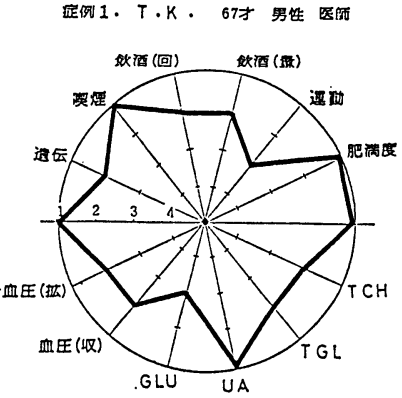

健晾後 4年 4力月

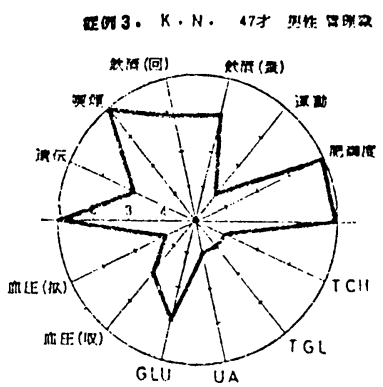

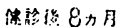

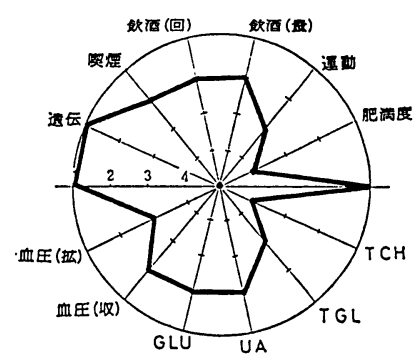

健晾後 2年 1 力月

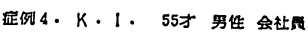

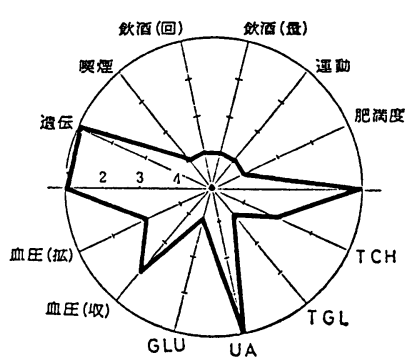

傮診後6力月
次予防の重要性と実現の可能性が述べられている。欧米 ではこの当時において，即に10年近くの一次予防の実験 的研究が実施済であり，生活習慣の改善により心筋硬塞 の一次予防が実現しらることが証明されている。この総 説には 4 つのプロジェクトチームの成績が引用されてい るが，共通の所見は血清総コレステロール平均値の 30 $\mathrm{mg} / \mathrm{dl}$ の低下である。今回われわれが検討した連続健診 受診者のコレステロール値は，連続受診によって低下し ておらず逆に上昇傾向さえみられた。要するに健診は一 次予防に役立っていないことを意味している。われわれ はこの原因として健診受診者への指導, 啓蒙の不足を考 えた。これの改善のためには, 受診者が理解し易い, 利
用し易い指導法の開発が必要である。われわれが作成し た指導表は，現時点では未だ不完全なものであるが，リ スクファクターの多い受診者を説得して改善の努力を決 意させる効力は備えている。従って, こう云った指導法 の開発への努力が, 自動化総合健診にとっての予見, 予 防へのアプローチと考えたい。

\section{文 献}

1) Stamler, J. : Primary prevention of coronary heart disease : The last 20 years. Amer. J. Cardiology, 47 : 722-735, 1981.

2) Stamler, J. : Acute myocardial infarctionprogress in primary prevention. British Heart J., 33 (Suppl.) : 145-164, 1971. 